\title{
Analisis Legal Standing Penerbitan Surat Keterangan Nikah oleh Kepala Desa Pada Pernikahan Siri di Desa Banjarsari Bekasi
}

\author{
Muhammad Faisal Hendriawan ${ }^{1}$, Elfirda Ade Putri ${ }^{2}$, Otih Handayani ${ }^{3}$ \\ ${ }^{123}$ Fakultas Hukum, Universitas Bhayangkara Jakarta Raya \\ Korespondensi: muhammadfaisal150298@gmail.com, elfirdade.putri@gmail.com, \\ otih.handayani@gmail.com
}

Info Artikel

Diterima : 14 Nop 2020 Direvisi : 2 Des 2020 Disetujui : 5 Des 2020 Diterbitkan : 7 Des 2020

DOI: https://doi.org/10.31599/krtha.v14i2.389

Keywords : legal standing, marriage certificate, family

Abstract : The purpose of marriage is to form a happy and eternal family (household) based on the Supreme Lordship. To achieve these objectives, socialization of laws and regulations for the public and enforcement of regulations by authorized government officials is required. This researcher aims to examine the application of the rules or norms in positive law which are then linked to the discussion that becomes the subject of discussion. normative juridical legal research is carried out by examining formal legal rules such as laws, regulations and literature containing theoretical concepts. The results of the study describe that based on the description of the village head, a marriage certificate was issued by the village head and village officials of Banjarsari Bekasi to the village community who carried out a marriage by band. This is intended to provide relief in fulfilling administrative requirements for the production of important documents. Based on the prevailing laws and regulations, the Village Head and Village Officials do not have the legal standing to issue a Marriage Certificate so that they have the potential to violate Law No. 1 of 1974 concerning Marriage, Law no. 30 of 2014 concerning Government Administration wbich results in a Marriage Certificate is not valid according to law and the Village Head may be subject to administrative sanctions.

Kata kunci : legal standing, surat keterangan nikah, keluarga

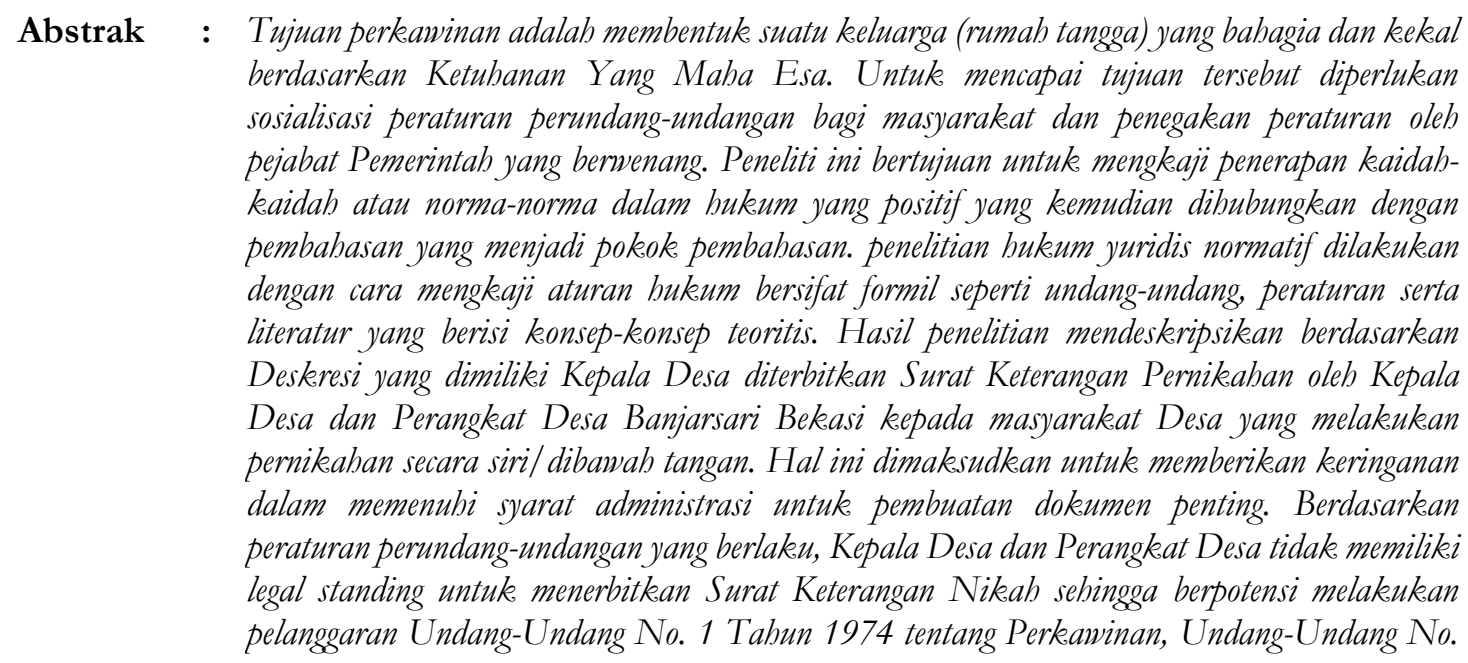


30 Tabun 2014 tentang Administrasi Pemerintaban yang mengakibatkan Surat Keterangan Nikah tidak sah menurut hukum serta kepada Kepala Desa dapat dikenakan sanksi administrasi.

\section{PENDAHULUAN}

Tujuan dari perkawinan itu adalah membentuk suatu keluarga sakinah mawaddah warrahmah. Perlu di atur dengan syarat rukun tertentu, agar tujuan yang disyariatkan perkawinan tercapai. Perkawinan yang diharapkan sesuai dengan hukum Positif yang berlaku atau yang ada yaitu ikatan lahir batin antara pria dan wanita sebagai suami istri dengan tujuan membentuk Keluarga/rumah tangga yang bahagia dan kekal berdasarkan Ketuhanan Yang Maha Esa. Di indonesia terdapat tiga macam sifat susuanan kekeluargaan yaitu : Patrilineal, Matrilineal, dan Parental. ${ }^{1}$

Sejak diberlakukannya Undang-undang Nomor 1 Tahun 1974 tentang Perkawinan, yang berlaku untuk seluruh rakyat Indonesia dan di seluruh wilayah Indonesia, maka sejak itulah perkawinan harus didasarkan pada Undang-undang Nomor 1 Tahun 1974 serta peraturan pelaksanaannya dan semua peraturannya yang mengatur tentang perkawinan sejauh telah diatur dalam undang-undang ini dinyatakan tidak berlaku lagi. ${ }^{2}$

Undang-Undang Perkawinan (UU No. 1 tahun 1974) bertujuan mengatur pergaulan hidup yang sempurna, bahagia dan kekal dalam suatu rumah tangga guna treciptanya rasa kasih sayang dan saling mencintai. Namun kenyataan sejarah umat manusia yang telah berusia ribuan tahun telah membuktikan bahwa tidak selalu itu dapat dicapai; bahkan sebaliknya kandas ataupun gagal sama sekali di tengah jalan, karena tidak tercapainya kata sepakat atau karena olehnya salah satu pihak ataupun perilaku kedua belah pihak yang bertentangan dengan ajaran agama.

Dalam kehidupan di masyarakat banyak terjadi perkawinan tanpa adanya pencatatan oleh negara, atau yang dikenal pernikahan. Pernikahan siri merupakan persoalan aktual yang patut untuk diperbincangkan. Dalam berbagai seminar dan diskusi, tema pernikahan siri seringkali ditemukan hanya karena keberadaannya yang kontroversial. Pada satu sisi ada yang beranggapan nikah siri adalah sah menurut pandangan agama, namun pada sisi lain tidak sedikit yang "menganggur" nikah siri lantaran dampak negatif yang ditimbulkan akibat tidak meiliki kekuatan hukum secara formal. ${ }^{3}$

\footnotetext{
${ }^{1}$ Soerjono Wignjodipoegoro, Pengantar Dan Asas-asas Hukum Adat, (Jakarta : Penerbit CV Haji Masangung), hlm. 127-128

${ }^{2}$ Sajuti Thalib, Hukum Keluarga Indonesia, (Jakarta : Universitas Indnesia, 1986), hlm. 47

${ }^{3}$ Burhanuddin S. 2010. Menjawab Semua Pertanyaan tentang Nikah siri. Pustaka Yustisia Yogyakarta
} 
Sesungguhnya melarang pernikahan siri sama halnya dengan mengantisipasi akibat buruk yang mungkin terjadi dalam kehidupan rumah tangga. Meskipun berbagai upaya untuk mencegah pernikahan siri sedang digalakkan, namun tetap saja ada yang mempraktekannya. Adapun sebabnya, tentu tidak lepas dari justifikasi, bahwa perkawinan adalah sah apabila dilakukan menurut hukum masing-masing agama dan kepercayaan itu. Tetapi siapa yang berwenang melangsungkan pernikahan, seperti belum ada ketentuan yang pasti. ${ }^{4}$

Pernikahan dalam Islam merupakan kontra sosial ditandai adanya kesepakatan ijab qobul. Seperti halnya amalan manusia pada umumnya, suatu pernikahan akan bernilai ibadah apabila dalam pelaksanaanya sungguh-sungguh diniatkan untuk mendapatkan ridho Allah. Akan tetapi niat kepada Allah sebagai bukti keimanan tidak mencukupi, apabila tanda diikuti oleh kemauan yang kuat untuk mengarungi samudra pernikahan sesuai ketentuan syariat-Nya. Meskipun ketentuan rukun dan syariat nikah sebagaimana dituntunkan Rasulullah SAW telah sempurna, namun ada beberapa persoalan terkait pernikahan yang belum final, sehingga membuka ruang untuk menjadi perbedatan. Diantara persoalan tersebut adalah tentang pernikahan siri yang banyak mengundang kontroversi. ${ }^{5}$

Nikah siri sendiri berasal dari kata siri yang secara bahasa berarti sembunyi atau rahasia. Sebab jenis perkawinan ini pada umumnya dilaksanakan dengan dihadiri oleh kalangan terbatas, secara diam-diam dan tanpa adanya Pegawai Pencatat Nikah. Kontroversi sah dan tidaknya perkawinan ini seakan mempertegas adanya ambiguitas hukum ditengah masyarakat muslim Indonesia antara hukum formal dan agama (fiqh). Satu sisi pernikahan siri dikatakan sah dalam perspektif fiqh (jika telah terpenuhi syarat dan rukun), tanpa menghiraukan pencatatan perkawinan. Sementara pada dimensi hukum formal, pernikahan ini tidak diakui oleh hukum perdata nasional karena tidak ada pencatatan atau bukti tertulis yang berimplikasi pada konsekuensi administrasi dan legal standing dari perkawinan. Dalam hal ini, yang paling menderita dan menanggung kerugian dalam kasus pernikahan siri kebanyakan adalah pihak wanita.

Dalam rangka mengantisipasi persoalan tersebut, pemerintah merasa berkepentingan untuk mengeluarkan kebijakan regulasi (syiyasah syar'iyyah) yang mengatur tentang pencatatan pernikahan. Meskipun bukan menjadi bagian rukun dan syarat sahnya perawinan, pencatatan pernikahan mempunyai peranan penting dalam menciptakan

\footnotetext{
${ }^{4}$ Ibid

${ }^{5}$ Burhanuddin S. 2010. Menjawab Semua Pertanyaan tentang Nikah siri. Pustaka Yustisia Yogyakarta
} 
kemaslahan pernikahan secara resmi biasanya akan mendapatkan akta nikah. Pembuatan alat bukti bagi kedua belah pihak (suami-istri) untuk melakukan proses yang timbul akibat dari suatu pernikahan. ${ }^{6}$

Nikah siri yang dikenal oleh masyarakat Indonesia sekarang ini ialah pernikahan yang dilakukan dengan memenuhi rukun dan syarat yang ditetapkan agama, tetapi tidak dilakukan dihadapan Pegawai Pencatat Nikah sebagai aparat resmi pemerintah atau perkawinan yang tidak dicatatkan di Kantor Urusan Agama bagi yang beragama Islam atau di Kantor Catatan Sipil bagi yang tidak beragama Islam, sehingga tidak mempunyai akta nikah yang dikeluarkan oleh pemerintah. Perkawinan yang demikian dikalangan masyarakat selain dikenal dengan istilah nikah siri atau dikenal juga dengan sebutan nikah di bawah tangan. ${ }^{7}$

Sahnya suatu perkawinan ditinjau dari sudut keperdataan, apabila perkawian itu sudah dicatatkan atau didaftarkan pada Kantor Urusan Agama atau Kantor Catatan Sipil. Selama perkawinan itu belum terdaftar, maka perkawinan itu dianggap tidak sah menurut ketentuan hukum, walaupun telah memenuhi prosedur dan tata cara menurut ketentuan agama. Apabila ditinjau dari segi agama, pencatatan perkawinan hanyalah sebagai perbuatan administrasi saja dalam perkawinan tersebut dan tidak menentukan sah atau tidaknya perkawinan.

Penyebaran virus corona yang masif terjadi di Indonesia membuat beragam aktivitas masyarakat terganggu, salah satunya pernikahan. Pemerintah melalui Kementerian Agama telah mengeluarkan aturan, dimana pencatatan perkawinan hanya akan dilakukan di Kantor Urusan Agama (KUA), dan bagi mereka yang telah mendaftar sebelum tanggal 1 April 2020. Oleh karena itu, nikah siri menjadi sebuah "jalan tengah" bagi pasangan yang tetap ingin melangsungkannya selama masa pandemi ini.

Data yang di peroleh dari Desa Banjarsari terdapat beberapa masyarakat yang melakukan pernikahan secara sirih. Pada saat ini pemerintahan tersebut mengeluarkan surat keterangan yang dimana tertulis bahwasanya "Amil desa mengetahui pernikahan tapi tidak tercatat di Kantor Urusan Agama (KUA)". Surat keterangan tersebut dikeluarkan karena permintaan Dinas Kependudukan Catatan Sipil untuk keperluan mengurus Kartu Keluarga dan lainya sebagai pengganti dari kartu nikah. Akan tetapi hal tersebut bertentangan dengan hukum positif di indonesia, yaitu Pasal 2 ayat (1) Undang-Undang Nomor. 1 tahun 1974 menyebutkan: "Perkawinan adalah sah, apabila dilakukan menurut

\footnotetext{
${ }^{6}$ Ibid, Hal 10-12

${ }^{7}$ Burhanuddin S. 2010. Menjawab Semua Pertanyaan tentang Nikah siri. Pustaka Yustisia Yogyakarta
} 
hukum masing-masing agamanya dan kepercayaannya itu". Dan sebagai pembuatan hukum diperlukan adanya kepastian hukum, maka Pasal 2 ayat (2) menyebutkan: "Tiaptiap perkawinan dicatat menurut peraturan perundang-undangan yang berlaku”. Dimana surat tersebut diterbitkan oleh perangkat desa dengan tertulis bahwasanya "benar bahwa nama yg tertera adalah suami istri yang telah menikah di Desa Banjarsari di hadapan Amil desa pada tanggal pernikahan dilangsungkan, namun pernikahan tersebut tidak tercatat di Kantor Urusan Agama (KUA) Kecamatan Sukatani Kabupaten Bekasi”. Dimana surat tersebut diterbitkan oleh perangkat desa dengan tertulis bahwasanya "benar bahwa nama yg tertera adalah suami istri yang telah menikah di Desa Banjarsari di hadapan Amil desa pada tanggal pernikahan dilangsungkan, namun pernikahan tersebut tidak tercatat di Kantor Urusan Agama (KUA) Kecamatan Sukatani Kabupaten Bekasi” dengan memanfaatkan kewenangan Kepala Desa dengan menggunakan hak Diskresinya. sebagai mana di atur Dalam Undang Undang Nomor 6 Tahun 2014 tentang Desa.

State of the art penelitian ini diambil dari penelitian terdahulu dalam bentuk jurnal di antaranya penelitian oleh Khairun Nisa, H.A. Lawali Hasibuan \& Zaini Munawir Lubis Fakultas Hukum, Universitas Medan Area, Indonesia pada Jurnal Ilmiah Penegakan Hukum Vol 4 No. 2 tahun 2017 berjudul Aspek Hukum Pencatatan Perkawinan Menurut Hukum Indonesia Di Desa Tumpatan Nibung Kecamatan Batang Kuis Kabupaten Deli Serdang dengan kesimpulan bahwa perkawinan yang tidak dicatatkan pada Pegawai Pencatat Nikah, maka perkawinan tersebut dianggap tidak ada. ${ }^{8} \mathrm{Kebaruan}$ dari penelitian ini adalah analisis tentang legal standing penerbit Surat Keterangan Nikah oleh Kepala Desa atau Perangkat Desa yang salah dalam menjalankan kewenangan Deskresinya.

Penelitian ini mengunakan teori kepastian hukum menurut Utrecht, yaitu kepastian hukum mengandung dua pengertian, yaitu pertama, adanya aturan yang bersifat umum membuat individu mengetahui perbuatan apa yang boleh atau tidak boleh dilakukan, dan kedua berupa keamanan hukum bagi individu di kesewenangan pemerintah karena dengan adanya aturan yang bersifat umum itu individu dapat mengetahui apa saja yang boleh dibebankan atau dilakukan oleh Negara terhadap individu. ${ }^{9}$

Artikel ini bertujuan untuk menganalisis bagaimana aspek kepastian hukum penertiban surat keterangan nikah siri yang dikeluarkan oleh Kepala Desa dilihat dari perspektif undang-undang perkawinan dan bagaimana surat keterangan nikah siri yang

\footnotetext{
${ }^{8}$ Khairun Nisa, H.A. Lawali Hasibuan \& Zaini Munawir Lubis Aspek Hukum Pencatatan Perkawinan Menurut Hukum Indonesia Di Desa Tumpatan Nibung Kecamatan Batang Kuis Kabupaten Deli Serdang, Jurnal Ilmiah Penegakan Hukum Vol 4 No. 2 tahun 2017

${ }^{9}$ Eza Aulia, Dara Quthni Effida, Kodifikasi Hukum Islam Di Indonesia Dalam Perspektif Kepastian Hukum, Jurnal Ius Civile: Refleksi Penegakan Hukum dan Keadilan, Vol. 2 No. 2 Tahun 2018
} 
dikeluarkan oleh Kepala Desa memiliki kedudukan yang sama dapat dijadikan sebagai pengganti akta nikah.

\section{II.METODE PENELITIAN}

Metode yang digunakan dalam penelitian ini adalah penelitian yuridis normatif. penelitian yang fokus untuk mengkaji penerapan kaidah-kaidah atau norma-norma dalam hukum positifyang kemudian di hubungkan dengan pembahasan yang menjadi pokok penelitian. Dalam penelitian ini menggunakan Undang-Undang Perkawinan Nomor 1 Tahun 1974 Tentang Perkawinan, Undang-Undang No 16 Tahun 2019 sebagai Perubahan Atas Undang-Undang Nomor 1 Tahun 1974 tentang PerkawinanUndangUndang Nomor 32 Tahun 1954, Undang-Undang Nomor 6 Tabun 2014 tentang Desa. Data primer yang digunakan adalah wawancara dengan pihak-pihak yang terkait dan berkait langsung dengan penelitian di tempat. Data Sekunder yang digunakan adalah Buku-buku teks yang bersangkutan dengan penelitian ini, Kamus-kamus hukum, dan Jurnal-jurnal hukum.

\section{PEMBAHASAN}

Kasus penerbitan Surat Keterangan Pernikahan terjadi di Desa Banjarsari. Menurut data yang diperoleh dari Desa Banjarsari terdapat permasalahan bahwa masyarakat Desa itu masih melakukan pernikahan secara siri/dibawah tangan. Dalam surat yang diterbitkan oleh perangkat desa dengan tertulis bahwasanya "Benar bahwa nama yang tertera adalah suami istri yang telah menikah di Desa Banjarsari di hadapan Amil desa pada tanggal pernikahan dilangsungkan, namun pernikahan tersebut tidak tercatat di Kantor Urusan Agama (KUA) Kecamatan Sukatani Kabupaten Bekasi”.

Pada saat ini pemerintahan Desa Banjarsari memberikan keringanan kepada pelaku nikah siri dengan mengeluarkan Surat Keterangan Pernikahan dimana surat tersebut digunakan untuk keperluan memenuhi syarat administrasi untuk pembuatan dokumen penting seperti : Kartu Keluarga, Akta Kelahiran, Asuransi kesehatann (BPJS), Pendaftaran sekolah, Dan lain sebagainya.

Berdasarkan data yang diperoleh di lapangan, diketahui bahwa pada bulan JanuariJuni Tahun 2019 jumlah perkawinan siri/dibawah tangan sebanyak 24 pasangan, pada bulan Juni-Desember Tahun 2019 jumlah dari perkawinan siri/dibawah tangan sebanyak 17 pasangan, pada bulan Januari-Juni Tahun 2020 Jumlah perkawinan siri/dibawah tangan sebanyak 19 pasangan setiap bulannya tidak menentu, biasanya 2- 
4 pasangan yang mendaftar nikah siri atau biasanya dalam satu bulan itu tidak ada satu pasangan pun yang mendaftar untuk nikah siri.

Tanggapan masyarakat terhadap perkawinan Nikah Siri / di bawah tangan merupakan suatu hal yang tidak bisa di hindari bagi umat Islam dalam melaksanakan sebuah perkawinan, meskipun pada data tentang pengetahuan masyarakat terhadap kewajiban mencatatkan perkawinan pada pejabat yang berwenang yaitu Pegawai Pencatat Nikah di Kantor Urusan Agama di kecamatan tempat berdomisili telah diketahui, namun pernikahan dibawah tangan/nikah siri tetap terjadi. Hal yang demikian adalah merupakan hal yang sudah lazim/ lumrah meskipun masyarakat setempat mengetahui kewajiban akan mencatatkan perkawinan sebelum pelaksanaan perkawinan.

\section{A. Aspek Kepastian Hukum Penerbitan Surat Keterangan Nikah Siri Yang Dikeluarkan Oleh Kepala Desa Dalam Perspektif Undang-Undang Perkawinan}

Kementerian Agama menegaskan pernikahan selain harus dilakukan sesuai ajaran agama juga harus dicatat oleh petugas Kantor Urusan Agama (KUA) atau Kantor Catatan Sipil. Oleh karena itu nikah siri (tidak tercatat) tidak sesuai dengan peraturan perundangan-undangan yaitu Undang-Undang Nomor 1 tahun 1974 tentang Perkawinan. Hal ini sebagaimana Pasal 1 angka (2) Peraturan Menteri Agama Nomor 20 Tahun 2019 tentang Pencatatan Pernikahan.

Nikah sirri merupakan nikah yang bermasalah, tidak sesuai hukum negara sebab berdasarkan Peraturan Pemerintah Nomor 9 tahun 1975 sebagai peraturan tentang pelaksanaan Undang-Undang Nomor 1 tahun 1974 disebutkan bahwa perkawinan bagi penganut Islam dilakukan oleh pegawai pencatat, dengan tata cara pencatatan.

Sebelum ada Undang-Undang Nomor 1 tahun 1974, masalah pernikahan diatur dalam Undang-Undang Nomor 22 tahun 1946 yang menyebutkan perkawinan diawasi oleh pegawai pencatat nikah. Dalam negara yang teratur, segala hal-hal yang bersangkut paut dengan pendududuk harus dicatat, kelahiran, pernikahan, kematian dan sebagainya.

Pelayanan pencatatan nikah merupakan salah satu target reformasi birokrasi di lingkungan Ditjen Bimas Islam yang dilakukan melalui pendekatan sistemik, dia mengimbau masyarakat untuk tidak melakukan. praktik jasa layanan nikah siri. 
Pemerintah telah memberikan kemudahan bagi masyarakat untuk pelayanan nikah, seperti pembebasan biaya nikah jika dilaksanakan pada kantor KUA pada jam kerja.

Berdasarkan Pengertian Pasal 1 UU Perkawinan No.1 tahun 1974 yang menetapkan perkawinan berdasarkan Ketuhanan Yang Maha Esa dapat ditafsirkan 2 hal berikut:

1) Di dalam negara Republik Indonesia yang berdasarkan Pancasila tidak boleh terjadi dan berlaku "Hukum Perkawinan" yang bertentangan dengan ajaran dan kaidah-kaidah Islam bagi orang-orang Islam. dan demikian pula bagi orang-orang yang beragama Nasrani, Hindu, Budha, dan Kong $\mathrm{Hu} \mathrm{Cu}$ tidak boleh terjadi dan berlaku hukum perkawinan yang bertentangan dengan ajaran dan kaidah-kaidah agama mereka.

2) Negara Republik Indonesia wajib menjalankan syari'at atau Hukum Perkawinan Islam bagi orang Islam, dan demikian pula bagi orang Nasrani, Hindu, Budha, dan Kong $\mathrm{Hu} \mathrm{Cu}$ negara wajib menjalankan hukum Perkawinan itu memerlukan bantuan atau perantaraan Negara.

Menurut Utrecht kepastian hukum mengandung dua pengertian yaitu: Pertama adanya aturan yang bersifat umum membuat individu mengetahui perbuatan apa yang boleh atau tidak boleh dilakukan dan, kedua berupa keamanan hukum bagi individu dikesewenangan pemerintah karena dengan adanya aturan yang bersifat umum itu individu dapat mengetahui apa saja yang boleh dibebankan oleh negara terhadap individu. $^{10}$

Berdasarkan Pasal 26 Undang-Undang Nomor 6 Tahun 2014 Tentang Desa Kepala Desa mempunyai tugas untuk menyelenggarakan Pemerintahan Desa, melaksanakan Pembangunan Desa, pembinaan kemasyarakatan Desa, dan pemberdayaan masyarakat Desa. ${ }^{11}$ Sebagai Pejabat Pemerintah Kepala Desa juga memiliki kewenangan yang disebut Deskresi.

Pasal 1 angka (9) Undang Undang Nomor 30 Tahun 2014 tentang Administrasi Pemerintahan mendefinisikan diskresi sebagai keputusan, tindakan yang ditetapkan, dilakukan oleh pejabat pemerintahan dalam rangka mengatasi persoalan konkret yang dihadapi dalam penyelenggaraan pemerintahan apabila peraturan perundang-undangan yang memberikan pilihan, tidak lengkap, tidak mengatur, atau tidak jelas, dan atau adanya

10 Dminikus Rato, Filsafat Hukum Mencari: memahami dan memahami bukum, Laksbang Pressindo, Yogyakarta,2010,hlm.59.

${ }^{11}$ Undang-Undang Nomor 6 Tahun 2014 Tentang Desa Kepala Desa pasal 26 
stagnasi pemerintahan. ${ }^{12}$ Adapun pejabat pemerintahan yang maksud adalah adalah unsur yang melaksanakan fungsi Pemerintahan, baik di lingkungan pemerintah maupun penyelenggara negara lainnya dari tingkat Presiden hingga Kepala Desa.

Pasal 24 huruf (b) Undang Undang Nomor 30 Tahun 2014 menyatakan bahwa dalam menjalankannya deskresinya Pejabat Pemerintah tidak boleh bertentangan dengan ketentuan perundang-undangan. Adapun pelanggaran terhadap kewenangan deskresi dikenakan sanksi adminstrasi baik ringan, sedang, maupun berat sebagaimaan diatur dalam Peraturan Pemerintah (PP) Nomor 48 Tahun 2016 tentang Tata Cara Pengenaan Sanksi Administrasi Kepada Pejabat Pemerintahan. ${ }^{13}$

Berdasarkan uraian tentang deskresi di atas maka, Kepala Desa maupun Perangkat Desa tidak mempunyai kewenangan sekalipun menggunakan Hak Diskresinya untuk menerbitkan Surat Keterangan Pernikahan, hal ini disebabkan ketentuan perundangundangan perihal pernikahan yang sah di Indonesia telah diatur dalam Undang-Undang No. 1 Tahun 1974 tentang Perkawinan, oleh karenanya dalam hal maka Kepala Desa atau Perangkat Desa menerbitkan Surat Keterangan Nikah Siri maka hal ini dapat dikatakan telah melakukan pelanggaran hukum dimana melaksanakan wewenang lain akan tetapi tidak sesuai dengan ketentuan peaturan perundang-undangan sebagaimana di atur pada Pasal 26 ayat (1) huruf (p) Undang-Undang Nomor 6 Tahun 2014 Tenang Desa yang dimana menjelaskan "kepala Desa Berwewenang melaksanakan wewenang lain yang sesuai dengan ketentuan peraturan perundang-undangan.” Selain itu Kepala Desa dapat dikenakan sanksi sebagaimana yang tertera di pasal 28 yaitu:

1) Kepala Desa yang tidak melaksanakan kewajiban sebagaimana dimaksud dalam Pasal 26 ayat (4) dan Pasal 27 dikenai sanksi administratif berupa teguran lisan dan/atau teguran tertulis.

2) Dalam hal sanksi administratif sebagaimana dimaksud pada ayat (1) tidak dilaksanakan, dilakukan tindakan pemberhentian sementara dan dapat dilanjutkan dengan pemberhentian.

Dengan demikian Surat Keterangan Pernikahan Siri yang diterbitkan oleh Kepala Desa ataupun Perangkat Desa bukan hanya tidak mempunyai kepastian hukum tetapi juga dapat mengakibatkan Kepala Desa dapat dikenakan sanksi admistrasi selain itu hal ini

\footnotetext{
12 https://www.hukumonline.com/klinik/detail/ulasan/lt54b538f5f35f5/arti--tujuan--lingkup--dancontoh-diskresi

13 https://setkab.go.id/pp-no-482016-inilah-aturan-tata-cara-pengenaan-sanksi-adminisratif-kepadapejabat-pemerintahan/
} 
mencerminkan keengganan Kepala Desa dan Perangkat Desa melaksanakan kewajibannya untuk mensosialisasikan Undang-Undang Perkawinan kepada warga masyarakatnya.

\section{B. Kedudukan Surat Keterangan Nikah Siri Yang Dikeluarkan Oleh Kepala Desa Sebagai Pengganti Akta Nikah}

Dalam masyarakat Indonesia Salah satu bentuk Perkawinan yang dikenal adalah Nikah Siri yaitu nikah yang dilakukan secara sembunyi-sembunyi, ada yang dicatat tapi disembunyikan dari masyarakat dan ada juga yang tidak dicatatkan pada Petugas Pencatat Nikah (PPN) dan tidak terdaftar di Kantor Urusan Agama (KUA) . Nikah seperti ini tidak sesuai dengan Hadist Rasul dimana Rasul menyuruh masyarakat yang menikah untuk mengumumkan pernikahannya dengan walimah (kenduri/syukuran).

Ada dua pemahaman tentang makna nikah siri di kalangan masyarakat Indonesia. Yang pertama, Nikah siri dipahami sebagai sebuah akad nikah yang tidak dicatatkan di Pegawai Pencatat Nikah, namun syarat dan rukunnya sudah sesuai dengan hukum Islam. Yang kedua, Nikah siri didefinisikan sebagai pernikahan yang dilakukan tanpa wali nikah yang sah dari pihak perempuan.

Dalam UU Perkawinan No.1 Tahun 1974 Pasal 1 merumuskan perkawinan adalah ikatan lahir dan batin antara seorang pria dengan seorang wanita untuk membentuk rumah tangga yang bahagia dan kekal berdasarkan Ketuhanan Yang Maha Esa. Pasal 2 ayat (1) dengan sangat jelas dan tegas menyebutkan: "suatu perkawinan sah apabila dilakukan menurut masing-masing agama dan kepercayaannya". Dilanjutkan dengan pasal 2 ayat (2), bahwa "Tiap-tiap perkawinan dicatat menurut peraturan UU yang berlaku".

Pengertian Pasal 1 UU Perkawinan No.1 tahun 1974 yang menetapkan perkawinan berdasarkan Ketuhanan Yang Maha Esa dapat ditafsirkan 2 hal berikut:

1) Di dalam negara Republik Indonesia yang berdasarkan Pancasila tidak boleh terjadi dan berlaku "Hukum Perkawinan" yang bertentangan dengan ajaran dan kaidah-kaidah Islam bagi orang-orang Islam, dan demikian pula bagi orang-orang yang beragama Nasrani, Hindu, Budha, dan Kong $\mathrm{Hu} \mathrm{Cu}$ tidak boleh terjadi dan berlaku hukum perkawinan yang bertentangan dengan ajaran dan kaidah-kaidah agama mereka.

2) Negara Republik Indonesia wajib menjalankan syari'at atau Hukum Perkawinan Islam bagi orang Islam, dan demikian pula bagi orang Nasrani, Hindu, Budha, dan Kong $\mathrm{Hu} \mathrm{Cu}$ negara wajib menjalankan hukum Perkawinan itu memerlukan bantuan atau perantaraan Negara. 
Terjadinya akad perkawinan menurut hukum masing-masing (Pasal 1 (1) UU No.1974) adalah merupakan peristiwa hukum. Peristiwa hukum tidak bisa dianulir adanya "peristiwa penting" yang ditentukan pada Pasal 2 ayat (2) bahwa "tiap-tiap perkawinan dicatat menurut peraturan perundang-undangan yang berlaku". Hal ini sejalan dengan penjelasan Pasal 2 dengan perumusan pada Pasal 2 ayat (1) tidak ada perkawinan diluar hukum masing-masing agamanya dan kepercayaannya itu, sesuai dengan UUD NRI 45.

Sedangkan menurut Diktum dalam Pasal KHI menentukan bahwa Perkawinan adalah sah, apabila dilakukan menurut Hukum Islam sesuai dengan Pasal 2 ayat (1) UU No.1 Tahun 1974 yaitu perkawinan yang dilakukan menurut hukum agama. Dengan demikian Pasal 4 KHI ini mempertegas bahwa perkawinan yang sah adalah perkawinan menurut Hukum Islam sesuai dengan Pasal 2 ayat (1) UU No.1 Tahun 1974 tentang Perkawinan.

Adapun pencatatan nikah tidak terkait dengan sah dan tidaknya akad perkawinan, karena pencacatan bukan peristiwa hukum, melainkan peristiwa penting biasa. Untuk itu, Pasal 5 KHI mempertegas bahwa pencatatan perkawinan diperlukan untuk:

1) Agar terjamin ketertiban perkawinan bagi masyarakat Islam setiap perkawinan harus dicatat. Pencatatan perkawinan sebagaimana tersebut pada ayat (1) dilakukan oleh Pegawai Pencatat Nikah (PPN) sebagaimana diatur dalam UU No.22 Tahun 1946.Dan UU No.32 Tahun 1954.

2) Agar ada jaminan ketertiban, maka Pasal 6 KHI merumuskan: Untuk memenuhi Pasal 5, setiap perkawinan harus dilangsungkan dan dibawah pengawasan Pegawai Pencatat Nikah.

Perkawinan yang dilakukan diluar pengawasan PPN tidak mempunyai kekuatan hukum. Diktum Pasal 6 ayat (2) KHI ini bertentangan atau tidak sesuai dengan ketentuanketentuan lainnya dalam KHI, misalnya:

1) Ketentuan Pasal 2 KHI yang merumuskan bahwa "perkawinan menurut Hukum Islam adalah akad yang sangat kuat atau mistaaqan ghalizhan untuk menaati perintah Allah dan melakukannya merupakan ibadah".

2) Pasal 3 KHI merumuskan tujuan perkawinan, yaitu untuk mewujudkan kehidupan rumah tangga yang sakinah, mawaddah, dan rahmah. 
3) Pasal 4 KHI yang menentukan sahnya perkawinan menurut Hukum Islam sesuai dengan Pasal 2 ayat (1) UU No.1 Tahun 1974 tentang perkawinan.

Akibat Hukum Pernikahan Siri ditinjau dari Undang-Undang Nomor 1 Tahun 1974 Tentang Perkawinan dan Kompilasi Hukum Islam, Nikah siri yang tidak tercatat pada Pejabat Pencatat Nikah (PPN) atau tidak terdaftar di Kantor Urusan Agama (KUA) dan apabila tidak memenuhi syarat dan rukun pernikahan menurutagama, maka pernikahan tersebut tidak mempunyai kekuatan legal formal, dan tidak ada akibat hukum, Nikah Siri dapat merugikan istri dan anak.

Sikap Pengadilan Agama apabila tidak ada buku nikah maka Pengadilan Agama tidak dapat memproses persidangan kecuali pemohon mengajukan permohonan Isbat (pengesahan pernikahan) dulu untuk permohonan Sidang cerai dan keperluan lain bagi perkawinan Siri yang tidak dicatat.

Artinya perkawian yang tidak dilakukan atau diawasi oleh Pegawai Pencatat Nikah atau perangkat KUA tidak mempunyai kekuatan hukum dimana sudah di jelaskan ditas pada Pasal 6 ayat (2) KHI.

Ditinjau pula dari Undang-Undang Nomor 1 Tahun 1974 Tentang perkawinan dan Kompilasi Hkum Isalam (KHI) sebagaimana telah dijelaskan di atas. Maka jelasnya Surat Keterangan Pernikahan yang diterbitkan oleh Kepala Desa tidak memiliki kepastian hukum dan tidak dapat pula menggantikan kedudukan Akta Nikah sebagai bukti yang legal di mata hukum.

\section{KESIMPULAN}

Berdasarkan uraian hasil penelitian di atas penulis menyimpulkan beberapa hal yaitu: Pertama, penerbitan Surat Keterangan Nikah Siri yang dikeluarkan oleh Kepala Desa dilihat dari perspektif undang-undang perkawinan tidak memiliki kepastian hukum, hal ini disebabkan perkawinan yang sah adalah perkawinan yang dilaksanakan berdasarkan agama dan kepercayaannya serta didaftarkan pada Kantor Urusan Agama / Kantor Catatan Sipil; Kepala Desa tidak memiliki wewenang untuk mengeluarkan akta nikah, adapun yang berwenang mengeluarkan Akta Nikah adalah Kantor Urusan Agama / Kantor Catatan Sipil sehingga dengan demikian Surat Keterangan Nikah Siri yang dikeluarkan oleh Kepala Desa tidak memiliki kekuatan hukum yang mengingat bagi para pihak yang menikah. Kedua, dikarenakan Surat Keterangan Nikah Siri yang dibuat oleh Kepala Desa tidak 
memiliki kekuatan hukum maka dengan sendirinya tidak dapat dipersamakan dengan Akta Nikah (Surat Keterangan Nikah Siri tidak dapat menggantikan Akta Nikah).

\section{DAFTAR PUSTAKA}

\section{Buku}

Angger Jati Wijaya dkk (Ed.), 2000 Reformasi Tata Pemerintaban Desa Menuju Demkrasi, Yogyakarta, Pustaka Pelajar.

Burhanuddin S. 2010, Menjawab Semua Pertanyaan Tentang Nikah Siri, Pustaka Yustisia Yogyakarta

Dminikus Rato, 2010, Filsafat Hukum Mencari: Memahami Dan Memahami Hukum, Yogyakarta, Laksbang Pressindo.

Koerniatmanto Soetoprawiro, 1994, Pemerintahan \& Peradilan Di Indonesia (Asal Usul dan Perkembangannya), Bandung, Citra Aditya Bakti.

Sajuti Thalib, 1986, Hukum Keluarga Indonesia, Jakarta, Universitas Indonesia.

Suhartono, dkk, 2001, Politik Lokal, Perlemen Desa : Awal Kemerdekaan Sampai Jaman Otonomi Daerah, Yogyakarta, Lapera Pustaka Utama.

\section{Jurnal}

Eza Aulia, Dara Quthni Effida, Kodifikasi Hukum Islam Di Indonesia Dalam Perspektif Kepastian Hukum, Jurnal Ius Civile: Refleksi Penegakan Hukum dan Keadilan, Vol. 2 No. 2 Tahun 2018

Khairun Nisa, H.A. Lawali Hasibuan \& Zaini Munawir Lubis Aspek Hukum Pencatatan Perkawinan Menurut Hukum Indonesia Di Desa Tumpatan Nibung Kecamatan Batang Kuis Kabupaten Deli Serdang, Jurnal Ilmiah Penegakan Hukum Vol 4 No. 2 tahun 2017

\section{Peraturan perundang-undangan}

Undang-Undang No. 1 Tahun 1974 tentang Perkawinan

Undang-Undang No. 30 Tahun 2014 tentang Administrasi Pemerintahan

Undang-Undang Nomor 6 Tahun 2014 Tentang Desa Kepala Desa

\section{Internet}

https://www.hukumonline.com/klinik/detail/ulasan/lt54b538f5f35f5/arti--tujuan-lingkup--dan-contoh-diskresi

https://setkab.go.id/pp-no-482016-inilah-aturan-tata-cara-pengenaan-sanksiadminisratif-kepada-pejabat-pemerintahan/ 